\title{
Antifungal and cytotoxicity activities of the fresh xylem sap of Hymenaea courbaril L. and its major constituent fisetin
}

\author{
Maysa Paula da Costa ${ }^{1}$, Marize Campos Valadares Bozinis ${ }^{3}$, Wanessa Machado Andrade ${ }^{3}$, Carolina Rodrigues Costa ${ }^{1}$, \\ Alessandro Lopes da Silva², Cecília Maria Alves de Oliveira², Lucília Kato², Orionalda de Fátima Lisboa Fernandes ${ }^{1}$, \\ Lúcia Kioko Hasimoto Souza ${ }^{1}$ and Maria do Rosário Rodrigues Silva ${ }^{1 *}$
}

\begin{abstract}
Background: The great potential of plants as Hymenaea courbaril L (jatoba) has not yet been throughly explored scientifically and therefore it is very important to investigate their pharmacological and toxicological activities to establish their real efficacy and safety. This study investigated the cytotoxicity of xylem sap of Hymenaea courbaril $\mathrm{L}$ and its bioactivity against the fungi Cryptococcus neoformans species complex and dermatophytes.

Methods: The fresh xylem sap of $\mathrm{H}$. courbaril was filtered resulting in an insoluble brown color precipitate and was identified as fisetin. In the filtrate was identified the mixture of fisetinediol, fustin, 3-O-methyl-2,3-trans-fustin and taxifolin, which were evaluated by broth microdilution antifungal susceptibility testing against $C$. neoformans species complex and dermatophytes. The fresh xylem sap and fisetin were screened for cytotoxicity against the 3T3-A31 cells of Balb/c using neutral red uptake (NRU) assay.

Results: The fresh xylem sap and the fisetin showed higher in vitro activity than the filtrate. The xylem sap of $H$. courbaril inhibited the growth of dermatophytes and of $C$. neoformans with minimal inhibition concentration (MIC) $<256 \mu \mathrm{g} / \mathrm{mL}$, while the fisetin showed MIC $<128 \mu \mathrm{g} / \mathrm{mL}$ for these fungi. Fisetin showed lower toxicity $\left(I C_{50}=158 \mu \mathrm{g} / \mathrm{mL}\right)$ than the fresh xylem sap $\left(I C_{50}=109 \mu \mathrm{g} / \mathrm{mL}\right)$.
\end{abstract}

Conclusion: Naturally occurring fisetin can provide excellent starting points for clinical application and can certainly represent a therapeutic potential against fungal infections, because it showed in vitro antifungal activity and low toxicity on animal cells.

Keywords: Antifungal activity, Cytotoxicity, Hymenaea courbaril

\section{Background}

Covering about a quarter of Brazil, the cerrado is the nation's second largest biome after the Amazon and it is characterized by different vegetation physiognomies, comprising savanna-like formations, forest forms, and also gallery forests $[1,2]$. The endemic plants are adapted to drought and fire, and this may be responsible for the large diversity in their secondary metabolites. In central Brazil, a substantial part of the population relies on medicinal plants for primary health care. The great potential of

\footnotetext{
* Correspondence: rosario@ufg.br

${ }^{1}$ Instituto de Patologia Tropical e Saúde Pública, Universidade Federal de Goiás, Rua 235 - s/n - Setor Universitário, CEP: 74605050 Goiânia, Goiás, Brazil Full list of author information is available at the end of the article
}

these plants has not yet been thoroughly explored scientifically and therefore it is very important to investigate the pharmacological and toxicological activity of these herbs to establish their real efficacy and safety. From our screening program, we selected Hymenaea courbaril L. (Fabaceae) a medicinal species popularly known in Brazil as 'jatoba' which has a long history of use as medicinal plant by indigenous tribes of the Amazon Basin and also in caatinga and cerrado communities. The jatoba bark is used to give energy and stamina, as well as a tonic for the respiratory tract and for the treatment of urinary systems. The fruit is used to treat mouth ulcers, and the leaves and wood are used for diabetes. The "jatoba" is also used popularly for 
cystitis, hepatitis, prostatitis, coughs, bronchitis, for stomach problems as well as to treat mycoses of nails [3].

Scientific studies on the medicinal properties of $H$. courbaril revealed antimicrobial activity against Grampositive bacteria and dengue virus type-2 $[4,5]$. The secondary metabolites of this plant showed the presence of flavonoid fisetin as the major compound [6], probably responsible for the antimicrobial properties. Fisetin is a natural flavonoid of interest in cancer prevention and therapy because this compound is relatively non toxic compared to other chemotherapeutic agents used in cancer therapy [7-9]. Fisetin possesses antioxidant and anti-inflammatory activity and was found to be cytotoxic and antiangiogenic in vitro [10-12]. After systemic administration in mice, fisetin has shown interesting antitumor activity in several cancer models, including prostate, teratocarcinoma and lung carcinoma [12,13]. According to Touil et al. [12] fisetin was found to be several times less cytotoxic towards normal NIH 3T3 cells when compared to tumor cells, and this could give to this compound an important in vivo advantage in terms of therapeutic index.

The fungal infections represent a significant problem to health and are one of the causes of morbidity and mortality in the world. The dermatophytosis caused by filamentous fungi such as Microsporum spp, Trichophyton spp and Epidermophyton floccosum represents a serious medical problem affecting about $20-25 \%$ of the world's population [14]. This mycosis affects mainly human scalp, feet and hands, nails and interdigital areas involving the patient's life quality [15]. The cryptococcosis caused by yeasts of $C$. neoformans species complex is an opportunistic infection that frequently causes meningoencephalitis in patients with impaired immune systems [16-19]. In Brazil, cryptococcosis is diagnosed in course at the time of disease in about $6 \%$ of acquired immune deficiency syndrome (AIDS) patients $[20,21]$. According to the Center for Disease Control Prevention (CDC) cryptococcal meningitis kills about 624,000 people each year [19]. Drugs used for treatment of cryptococcosis and dermatophytosis have considerable side-effects and adverse effects accompanied by the development of resistance by microorganism with reduced ability to clear completely the infection [22-25].

Some reports have described the biological activities of leaves, seed and trunk resin of $H$. courbaril [26-29], but there is a lack of information on the xylem sap. In the present work, we have focused on the phytochemical study, cytotoxicity and antifungal activity of the fresh xylem sap of $H$. courbaril and its major compound fisetin (1).

\section{Methods}

\section{Extraction and isolation}

The fresh xylem sap (extracted from hole through the bark to heartwood from jatoba tree, $250 \mathrm{~mL}$ ), of $H$. courbaril was purchased in "Vaga-Fogo" Farm, Pirenopolis, Goiás, Brazil. The insoluble brown color precipitate was filtered through filter paper and it was analyzed by ${ }^{1} \mathrm{H}$ and ${ }^{13} \mathrm{C}$ NMR [Varian Mercury plus BB spectrometer, operating at 300.059 $\mathrm{MHz}\left({ }^{1} \mathrm{H}\right)$ and $75.458 \mathrm{MHz}\left({ }^{13} \mathrm{C}\right)$ using $\mathrm{CDCl}_{3}$ solutions with TMS as an internal standard] and was identified as fisetin $(1,10 \mathrm{mg})$.

The filtrate of fresh xylem sap was lyophilized, and the dried extract (2.6 g) was fractionated on silica gel 60 using a hexane/ethyl acetate mixture of increasing polarity to yield $30 \mathrm{mg}$ of the mixture of 4 compounds wich were eluted with hexane/ethyl acetate (20:80) and it were identified by the 1D and 2D NMR analysis. Fisetinediol (2); fustin (3); 3-O-methyl-2,3-trans-fustin (4) and taxifolin (5) were identified in the mixture. The NMR data were compared to literature (Mujwah et al. [30], Piacente et al. [31] and Baderschneider \& Winterhalter [32]).

\section{Structural elucidation}

Fisetin (1)

${ }^{1} \mathrm{H}$ NMR (300 MHz, MeOD) 6.88 (d; 8.1, H5'); 6.91 (d; 2.1, H8); 6.92 (dd; 8.7; 2.1, H6); 7.66 (dd; 8.1; 2.1, H6'); 7.76 (d; 2.1, H2'); 7.98 (d; 8.7, H5); ${ }^{13} \mathrm{C}$ NMR (75 MHz, MeOD): 103.0 (C8); 115.4 (C10); 115.9 (C2'); 116.0 (C5' and C6); 121.6 (C6'); "124.2 (C1'); "127.6 (C5); 138.6 (C3); "147.1 (C2, C3' and 4'); 158.5 (C9); *164.0 (C7); 173.4 (C4).

The profile in HPLC of crude extract was carried on a Shim-Pack CLC-ODS $(\mathrm{H})(4.6 \mathrm{~mm} \times 25 \mathrm{~cm})$ was performed on a Shimadzu LC8A system, using 30\% metanol $/ \mathrm{H}_{2} \mathrm{O}$ acidified with $0.3 \%$ formic acid as eluent. The Figure 1 shows a comparison of fisetin (1) and crude extract sap.

\section{Fisetinediol (2)}

${ }^{1}$ H NMR (300 MHz, MeOD) 2.67 (dd; 15,9; 7,8; H4a); 2.87 (dd; 15.9; 5.1; H4b); 3.99 (ddd; 7.8; 7.2; 5.1; H3); 4.63 (d; 7.2; H2); 6.27 (d; 2.4; H8); 6.33 (dd; 8.1; 2.4, H6); 6.69 (dd, 8.1; 2.1; H6'); 6.75 (d; 8.1; H5'); 6.81 (d; 2.1; H2'); 6.85 (d; 8.1;H5). ${ }^{13} \mathrm{C}$ NMR (75 MHz, MeOD): 33.1 (C4); 83.0 (C2); 68.8 (C3); 103.6 (C8); 109.4 (C6); 112.5 (C10); 115.1 (C2'); 116.1 (C5'); 119.8 (C6'); 131.3 (C5); 132.2 (C1'); 146.3 (C3');146.3 (C4');156.2 (C9); 157.9 (C7);

\section{Fustin (3)}

${ }^{1} \mathrm{H}$ NMR (300 MHz, MeOD) 4.47 (d; 11.7, H3); 4.92 $(\mathrm{H} 2) ; 6.26(\mathrm{~d} ; 2.1, \mathrm{H} 8) ; 6.35(\mathrm{dd} ; 8.9 ; 2.1, \mathrm{H} 6) ; 6.83$ (m, H6'); 6.89 (d; 8.4, H5'); 6.97 (d; 2.1, H2'); 7.67 (d; 8.9, H5); ${ }^{13} \mathrm{C}$ NMR (75 MHz, MeOD): 74.6 (C3); 85.5 (C2); 103.8 (C8); 109.3 (C6); *114.0 (C10); 115.9 (C2');116.2 (C5');120.9 (C6');*129.9 (C1');133.5(C5); *146.2 (C3 $\left.{ }^{\prime}\right) ;{ }^{*} 147.1 \quad$ (C4');"*166.9 (C9);"167.0 (C7); *205.0 (C4). 


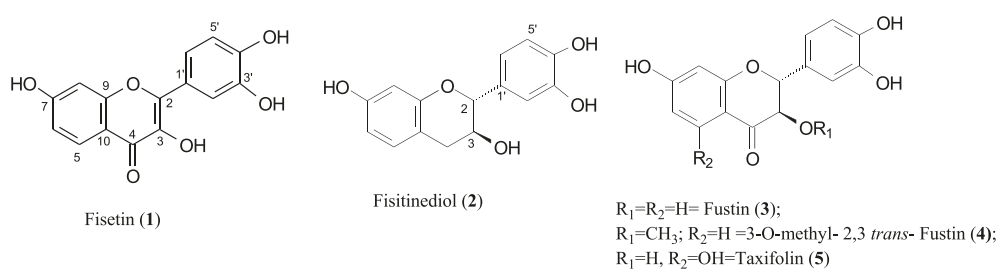

Figure 1 Chemical structures of the compounds 1-5.

\section{3-0-methyl-2,3-trans-fustin (4)}

${ }^{1} \mathrm{H}$ NMR (300 MHz, MeOD) 3.30 $\left(\mathrm{OCH}_{3}\right) ; 4.16$ (d; 10.2, H3); 5.06 (d; 10.2, H2); 6.32 (d; 2.1, H8); 6.51 (dd; 8.7; 2.1, $\mathrm{H6}) ; 6.79$ (d; 8.1, H5'); 6.83 (m, H6'); 6.93 (d; 2.1, H2'); 7.69 (d; 8.7, H5); ${ }^{13} \mathrm{C}$ NMR (75 MHz, MeOD): 60.6 $\left(\mathrm{OCH}_{3}\right) ; 83.4$ (C3); 84.2 (C2); 103.7 (C8); 112.2 (C6); *113.8 (C10);115.6 (C2');116.0 (C5'); 120.4 (C6');"129.9 (C1'); 130.1 (C5); *146.3 (C3');"*147.1 (C4');*166.9 (C9); *167.0 (C7); *205.0 (C4).

\section{Taxifolin (5)}

${ }^{1} \mathrm{H}$ NMR (300 MHz, MeOD) 4.49 (d; 11.4, H3); 4.89 (H2); 5.87 (d; 2.1; H8); 5.91 (d; 2.1; H6); 6.79 (d; 8.1, H5'); 6.83 (m, H6'); 6.95 (d; 2.1, H2'). ${ }^{13} \mathrm{C}$ NMR (75 $\mathrm{MHz}, \mathrm{MeOD}$ ): 73.7 (C3);85.1 (C2); 97.4 (C6); 96.4 (C8); 101.9 (C10); 115.8 (C2');116.0 (C5');120.9 (C6');129.9 (C1');147.1 (C3' and C4'); 164.0 (C9); *166.8 (C5); *169.0 (C7).

*The signal could be exchanged. "These signals were under the solvent signal, then were attributed by HSQC experiment.

\section{Fungal strains}

The microorganisms used in this study were obtained from the fungal collection of the Laboratory of Mycology (IPTSP - UFG), from previously work performed in Goiânia-GO at the 'Hospital das Clínicas' (HC-UFG) and the 'Hospital de Doenças Tropicais' approved by the respective hospitals ethics committees with protocols numbers $007 / 2004$ and 065/2008. These microorganisms comprised 18 strains of dermatophytes and 26 of C. neoformans species complex. The fungi were maintained on Sabouraud dextrose agar at $-70^{\circ} \mathrm{C}$ (Difco) and subcultured on the same medium for 72 hours before testing.

\section{In vitro susceptibility testing}

The in vitro activity of the sap of $H$. courbaril and the isolated compounds and mixture was evaluated using the broth microdilution method, as described in Clinical and Laboratory Standards Institute (CLSI) documents M27-A3 for yeasts and M38-A2 (with some modifications) for dermatophytes [33-35].

In a previous experiment, xylem sap and the compounds 1-5 were screened broth microdilution method against six isolates of dermatophytes and six of yeasts of C. neoformans species complex, with concentrations ranging from 256 to $0.25 \mu \mathrm{g} / \mathrm{mL}$ for both fungi. Posteriorly, according to results obtained, in vitro susceptibility tests were also performed using fresh xylem sap and fisetin against 18 dermatophytes and 26 yeasts, with concentrations ranging from 256 to $0.25 \mu \mathrm{g} / \mathrm{mL}$ for fresh xylem sap and from 128 to $0.125 \mu \mathrm{g} / \mathrm{mL}$ for fisetin.

Cell suspensions of $C$. neoformans were prepared from 3-day-old cultures in Sabouraud's dextrose agar at $28^{\circ} \mathrm{C}$ in sterile saline $(0.85 \%)$, and the optical density was adjusted using a spectrophotometer to $85 \%$ transmittance at a wavelength of $530 \mathrm{~nm}$. This suspension was diluted to 1:50 and then 1:20 in RPMI 1640 medium (Sigma Chemical Co., St. Louis, MO, USA) buffered to a $\mathrm{pH}$ of 7.0 with $0.165 \mathrm{~mol} / \mathrm{L}$ MOPS (Sigma Chemical Co.) to obtain a final inoculum of approximately 1 to $5 \times 10^{3} \mathrm{CFU} / \mathrm{mL}$ [33].

The inocula of dermatophytes were performed according to Santos et al. [35]. Briefly, the isolates were subcultured in potato dextrose agar at $28^{\circ} \mathrm{C}$ for 7 days to produce conidia. The fungal colonies were then covered with $5 \mathrm{~mL}$ of sterile saline $(0.85 \%)$, and suspensions were made by scraping the surface with the tip of a Pasteur pipette. The resulting conidia and hyphal particles were transferred to a sterile tube and allowed to settle for 15-20 min at room temperature. The density of the suspension was adjusted using a spectrophotometer at wavelength of $520 \mathrm{~nm}$ to a transmittance of 70 to $72 \%$. The resulting suspension was diluted to $1: 50$ in RPMI medium to obtain the final inoculum of approximately 2 to $4 \times 10^{4} \mathrm{CFU} / \mathrm{mL}$ [34].

The MIC values were determined after 5 days of incubation at $28^{\circ} \mathrm{C}$ for dermatophytes and after $72 \mathrm{~h}$ at $37^{\circ} \mathrm{C}$ for yeasts. The MIC was defined as the lowest concentration showing 100\% growth inhibition compared with growth in the control. Candida parapsilosis ATCC 22019 and C. neoformans ATCC 28957 were used as controls. Itraconazole (Sigma Chemical Co.) and DMSO diluted in the same way were included as quality controls. Each experiment was performed in duplicate.

\section{In vitro Cytotoxicity}

Cell viability was evaluated by neutral red uptake (NRU) according to Borenfreund and Puerner [36], modified by 
NICEATM-ICCVAM [37]. Briefly, a Balb/c 3T3-A31 fibroblast cell line was grown in DMEM-1640 [(Sigma ${ }^{\mathrm{TM}}, \mathrm{St}$ Louis, MO), high glucose medium containing 10\% FBS $\left(\right.$ Cultilab $\left.\left.^{\mathrm{TM}}\right)\right]$. The cells were harvested with trypsin/EDTA and seeded $(100 \mu \mathrm{L} /$ well $)$ at an initial density of $3 \times 10^{4}$ cells/mL into a 96-well plate and incubated overnight. After 24 hours of incubation at $37^{\circ} \mathrm{C}$, the cells were treated with eight different concentrations (256 to $2 \mu \mathrm{g} / \mathrm{mL}$ ) of fresh xylem sap or fisetin diluted in DMEM medium and incubated for $48 \mathrm{~h}$. The medium was aspirated and replaced with $250 \mu \mathrm{L}$ per well (including blank) of neutral red (NR) solution. After $3 \mathrm{~h}$ incubation $\left(37 \pm 1^{\circ} \mathrm{C}, 90 \pm 10 \%\right.$ humidity, $5 \pm 1 \% \mathrm{CO}_{2}$ /air) the NR medium was removed, and the cells were washed with pre-warmed PBS. The PBS was decanted and $100 \mu \mathrm{L}$ of an aqueous solution of $1 \%$ acetic acid: $50 \%$ ethanol $(\mathrm{v} / \mathrm{v})$ was added to each well to extract the dye. After rapid shaking $(20 \mathrm{~min})$ in a microtitre plate shaker, the absorbance was read at wavelength of $540 \mathrm{~nm}$.

Cytotoxicity tests were performed at least three times, using six wells for each concentration of fresh xylem sap or of fisetin. The data for the dose-response cytotoxicity curves are presented as the arithmetic mean and standard deviation. Linear regression analysis was used to compute the concentration that reduced absorbance by $50 \%\left(\mathrm{IC}_{50}\right)$. The NRU assay results are expressed as the percentage uptake of neutral red dye by lysosomes.

\section{Results}

The screening of in vitro antifungal susceptibility of fresh xylem sap, fisetin (1) and the mixture of fisinetidiol (2), fustin (3), 3-O methyl, 2,3-trans-fustin (4) and taxifolin (5) (Figure 1) of $H$. courbaryl showed that both yeasts (6 strains) and dermatophytes (6 strains) were more susceptible to fresh xylem sap and to fisetin than the mixture of compounds. In this screening, all the tested strains showed susceptibility to fisetin at concentrations of
32-128 $\mu \mathrm{g} / \mathrm{mL}$, while for xylem sap this concentration ranged of $32-256 \mu \mathrm{g} / \mathrm{mL}$.

In posterior evaluation against 44 isolates (18 dermatophytes and 26 yeasts), the fresh xylem sap of $H$. courbaril inhibited the growth of dermatophytes and of C. neoformans species complex with MIC values of $8-256 \mu \mathrm{g} / \mathrm{mL}$ and geometric means of $64-181 \mu \mathrm{g} / \mathrm{mL}$, while the fisetin showed a MIC of 4-128 $\mu \mathrm{g} / \mathrm{mL}$ and geometric means of $21.5-128 \mu \mathrm{g} / \mathrm{mL}$ for the fungi tested (Table 1). Quality controls performed with itraconazole showed MIC of $1 \mu \mathrm{g} / \mathrm{mL}$ and of $0.25 \mu \mathrm{g} / \mathrm{mL}$ for all isolates of dermatophytes and $C$. neoformans species complex, respectively.

The results of in vitro cytotoxicity showed lower toxicity of fisetin than of fresh xylem sap against 3T3-A31 cells of Balb/c with an $\mathrm{IC}_{50}$ of $109 \mu \mathrm{g} / \mathrm{mL}$ for fresh xylem sap of $H$. courbaril and of $158 \mu \mathrm{g} / \mathrm{mL}$ for fisetin. The percentage of growth inhibition of the 3T3-A31 cells increased with increasing concentrations of fresh xylem sap or fisetin as shown in Figure 2. Reduction in the amount of fibroblast cells 3T3-A31 treated with the fresh xylem sap and fisetin visualized by inverted light microscope is showed in Figure 3.

\section{Discussion}

Antifungal drugs available do not completely satisfy the medical necessity due to problems such as spectrum, potency, security, and their pharmacokinetic properties. Nowadays, there is an increased interest in searching for new antifungal compounds that function as selective and low toxic. Natural products may be used as templates for development of new drugs by the pharmaceutical industry and compounds extracted of plants have been considered the major resources of bioactive agents. It was estimated that at least 12000 active compounds have been isolated from medicinal plants as antimicrobial agents representing less than $10 \%$ of the total $[38,39]$.

Table 1 In vitro antifungal activity of the sap and fisetin of $\boldsymbol{H}$. courbaril

\begin{tabular}{|c|c|c|c|c|c|c|c|c|}
\hline \multirow[t]{3}{*}{ Isolates } & \multicolumn{8}{|c|}{ Minimum inhibitory concentration $(\mu \mathrm{g} / \mathrm{mL})$} \\
\hline & \multicolumn{4}{|c|}{ Fresh xylem sap } & \multicolumn{4}{|l|}{ Fisetin } \\
\hline & Range & $\mathrm{MIC}_{50}$ & $\mathrm{MIC}_{90}$ & GM & Range & $\mathrm{MIC}_{50}$ & $\mathrm{MIC}_{90}$ & GM \\
\hline \multicolumn{9}{|l|}{ Dermatophytes (n) } \\
\hline M. gypseum (2) & $64-128$ & 128 & 128 & 90.5 & $64-128$ & 128 & 128 & 90.5 \\
\hline T. mentagrophytes (8) & $32-128$ & 64 & 128 & 83 & $32-128$ & 64 & 128 & 69.8 \\
\hline T. rubrum (7) & $32-128$ & 64 & 128 & 64 & $4-64$ & 32 & 64 & 21.5 \\
\hline T. tonsurans (1) & 128 & 128 & 128 & 128 & 128 & 128 & 128 & 128 \\
\hline \multicolumn{9}{|l|}{ Yeasts (n) } \\
\hline C. gattii (4) & $128-256$ & 128 & 256 & 181 & 128 & 128 & 128 & 128 \\
\hline C. neoformans (22) & $8-256$ & 64 & 256 & 68,2 & 8-128 & 64 & 128 & 48.2 \\
\hline
\end{tabular}

$\mathrm{MIC}_{50}$ - inhibit the growth of $50 \%$ of isolates;

$\mathrm{MIC}_{90}$ - Minimal inhibitory concentration to inhibit the growth of $90 \%$ of isolates; $\mathrm{GM}=$ Geometric Mean. 

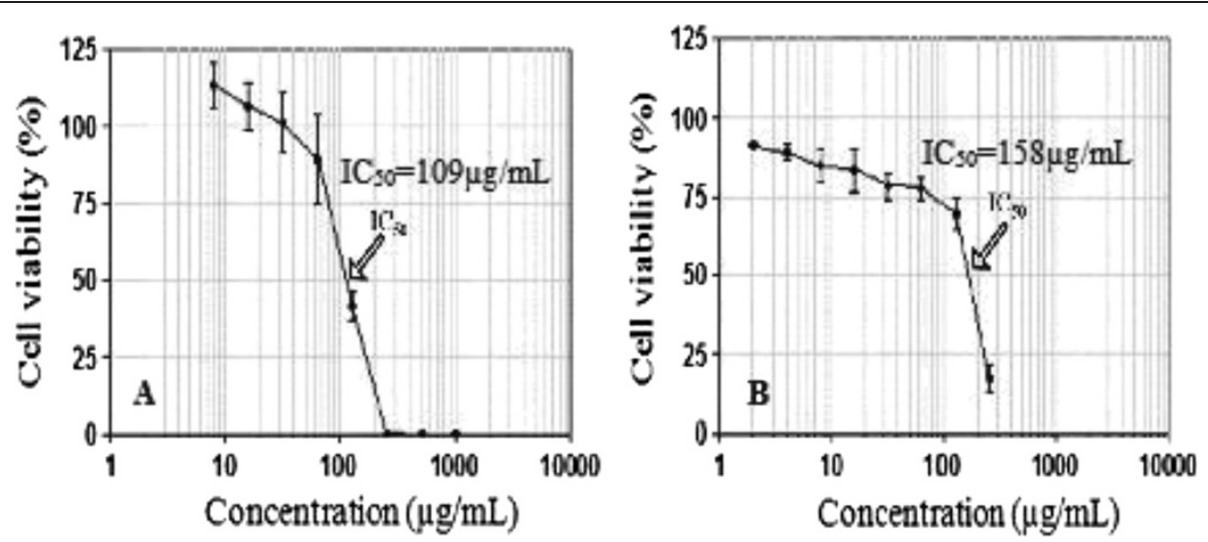

Figure 2 Cell viability of 3T3-A31 fibroblasts exposed to different concentrations of fresh xylem sap of $H$. courbaril (A) and of fisetin (B).

The present work has demonstrated the antifungal activity of fisetin and fresh xylem sap from $H$. courbaril, species largely found in Brazil, against yeasts of C. neoformans species complex and filamentous fungi as dermatophytes. Numerous assay systems and organisms have been used to screening plant extracts and constituents of active plants for antimicrobial activity. The broth microdilution method used in this work has several advantages. This method is quantitative, allows the use of small quantities of compounds or plant extracts as well as culture media [40]. It was observed MIC values below $256 \mu \mathrm{g} / \mathrm{mL}$ for fisetin and for fresh xylem sap against these fungi. There is no consensus in the literature on the MIC values of a plant extract which qualifies it as promising for fractionation. According to Kuete [40], the antimicrobial activity of extracts can be classified as follows: significant if MIC values are below100 $\mu \mathrm{g} / \mathrm{ml}$, moderate when $100<\mathrm{MIC}<625 \mu \mathrm{g} / \mathrm{ml}$ and weak if $\mathrm{MIC}>625 \mu \mathrm{g} / \mathrm{ml}$. Therefore, the overall antifungal activity exhibited in this study varied from moderate to significant. Previous studies have shown that flavonoids-rich extracts possesses antimicrobial activity [41,42]. Although the identification of mechanism action of flavonoids has been discussed in the literature and there are indications that antimicrobial proprieties of flavonoids are due to its interference with the specific intracellular of enzymes surface [43-45], a new studies to the identification of its mechanism action is still necessary.

In the present study, it was used NRU assay to determine the cytotoxic effect of fisetin and fresh xylem sap of $H$. courbaril in Balb/c 3T3-A31 fibroblast cell line to determine their $\mathrm{IC}_{50}$. Cell viability evaluation of fisetin showed $\mathrm{IC}_{50}$ of $158 \mu \mathrm{g} / \mathrm{mL}$ and of sap of $109 \mu \mathrm{g} / \mathrm{mL}$, with low reduction of number of cells visualized by inverted microscope (Figure 3). In this way, fisetin and xylem sap had good results of $\mathrm{IC}_{50}$ when compared to their MIC against Cryptococcus and dermatophytes. The xylem sap of $H$. courbaril inhibited the growth of dermatophytes and of the yeast $C$. neoformans species complex with MIC below $256 \mu \mathrm{g} / \mathrm{mL}$, while the fisetin showed MIC below $128 \mu \mathrm{g} / \mathrm{mL}$. Cell cytotoxicity assays are commonly used in vitro bioassay methods to predict the toxicity of substances in various tissues, because they demonstrate the degree of damage caused by the chemical [46].

The results obtained in this work, showed lower toxic effect of fisetin to mouse fibroblast cell line and higher activity against fungi than fresh xylem sap of $H$. courbaril. The naturally occurring flavonol, fisetin $\left(\mathrm{C}_{15} \mathrm{H}_{10} \mathrm{O}_{6}\right)$, is
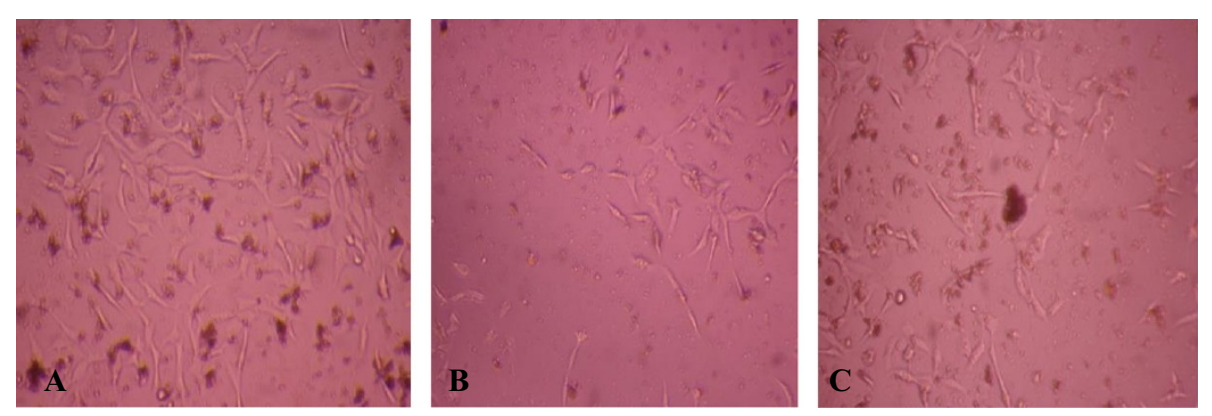

Figure 3 The cells of Balb/C untreated and treated with xylem sap and fisetin. A- The cell-fibroblast Balb/c 3T3-A31 untreated. B- Cells treated with fresh xylem sap of $\mathrm{H}$. courbaril at a concentration of $64 \mu \mathrm{g} / \mathrm{mL}$. C- Cells treated with fisetin 1 at a concentration of $128 \mu \mathrm{g} / \mathrm{mL}$. Photomicrograph at 200X by inverted microscope. 
produced ubiquitously in the plant kingdom and may be found in high concentrations in certain food plants, most notably grape, onion and cucumber [47].

\section{Conclusion}

Thus, fisetin, has advantage over the antifungals used commercially and can certainly represent a therapeutic potential due to in vitro antifungal activity and low toxicity on animal cells.

Although the results have suggested that fisetin may be useful as antifungal drug, further studies of pharmacokinetics and pharmacodynamics aspects are needed for utilization of this natural product.

\section{Competing interest}

The authors have no conflict of interests to declare.

\section{Authors' contributions}

MPC and MRRS: conceived and designed the work, drafted the manuscript, performed the experiments and contributed in analysis of data. MCVB and WMA: Contributed in the analysis of cytotoxicity. CMAO and LK provided the plant material and carried out the compounds extraction and HPLC analysis. CRC, LKHS and OFLF contributed in the analysis and interpretation of experiment data and participated in manuscript preparation. All authors gave their approval for the final version of the manuscript to be published.

\section{Acknowledgements}

The authors thank to Hildene Meneses e Silva for technical support. This work was supported by grants from Conselho Nacional de Desenvolvimento Científico e Tecnológico (CNPq), Coordenação de Aperfeiçoamento Pessoal de Nível Superior (CAPES) and Fundação Nacional de Pesquisa de Goiás (FUNAPE).

\section{Author details}

${ }^{1}$ Instituto de Patologia Tropical e Saúde Pública, Universidade Federal de Goiás, Rua 235 - s/n - Setor Universitário, CEP: 74605050 Goiânia, Goiás, Brazil. ${ }^{2}$ Instituto de Química, Universidade Federal de Goiás, Campus II Samambaia, Itatiaia, CEP: 74001-970 Goiânia, GO, Brazil. ${ }^{3}$ Faculdade de Farmácia, Universidade Federal de Goiás, Praça Universitária, Esq, c/1a Avenida, Qd 62, Setor Universitário, CEP: 74605-220 Goiania, GO, Brazil.

Received: 29 October 2013 Accepted: 6 June 2014

Published: 16 July 2014

\section{References}

1. Eiten G: Brazilian savannas. In Ecology of Tropical Savannas, Volume 42. Edited by Huntley BJ, Walker BH. Berlin: Springer-Verlag; 1982:25-47.

2. Redford $\mathrm{KH}$, Fonseca GAB: The role of Gallery Forests in the Zoogeography of the Cerrado's non-volant Mammalian Fauna. Biotropica 1986, 18:126-135.

3. Hussain $\mathrm{H}$, Hussain J, Al Harrasi A, Krohn K: The chemistry and biology of bicoumarins. Tetrahedron 2012, 68:2553-2578.

4. Fernandes TT, Santos AT, Pimenta FC: Atividade antimicrobiana das plantas Plathymenia reticulata, Hymenaea courbaril e Guazuma ulmifolia. Rev Patol Trop 2005, 34:113-122.

5. Zandi K, Teoh B, Sam S, Wong P, Mustafa MR, AbuBakar S: In vitro antiviral activity of fisetin, rutin and naringenin against dengue virus type- 2 . J Med Plants Res 2011, 5:5534-5539.

6. Correia AF, Segovia JFO, Gonçalves MSA, De Oliveira VL, Silveira D, Carvalho JCT, Kanzaki LIB: Amazonian plant crude extract screening for activity against multidrug-resistant bacteria. Eur Rev Med Pharmacol Sci 2008, 12:369-380.

7. Middleton E, Kandaswami C, Theoharides TC: The effects of plant flavonoids on mammalian cells: implications for inflammation, heart disease, and cancer. Pharmacol Rev 2000, 52:673-751.

8. Havsteen $\mathrm{BH}$ : The biochemistry and medical significance of the flavonoids. Pharmacol Ther 2002, 96:67-202.
9. Lopez-Lazaro M: Flavonoids as anticancer agents: structure-activity relationship study. Med Chem Anticancer Agents 2002, 2:691-714

10. Woodman OL, Chan EC: Vascular and anti-oxidant actions of flavonols and flavones. Clin Exp Pharmacol Physiol 2004, 31:786-790.

11. Park HH, Lee S, Oh JM, Lee MS, Yoon KH, Park BH, Kim JW, Song H, Kim SH: Anti-inflammatory activity of fisetin in human mast cells (HMC-1). Pharmacol Res 2007, 55:31-37.

12. Touil YS, Auzeil N, Boulinguez F, Saighi H, Regazzetti A, Scherman D, Chabot GG: Fisetin disposition and metabolism in mice: Identification of geraldol as an active metabolite. Biochem Pharmacol 2011, 82:1731-1739.

13. Tripathi R, Samadder T, Gupta S, Surolia A, Shaha C: Anti-cancer activity of a combination of cisplatin and fisetin in embryonal carcinoma cells and xenograft tumors. Mol Cancer Ther 2011, 10:255-268.

14. Bassiri-Jahromi S, Khaksari AA: Epidemiological survey of dermatophytosis in Tehran, Iran, from 2000 to 2005. IJDVL 2009, 75:142-147.

15. Havlickova B, Czaika VA, Friedrich M: Epidemiological trends in skin mycoses worldwide. Mycoses 2008, 51:02-15.

16. Lindenberg ASC, Chang MR, Paniago AMM, Lazéra MS, Moncada PMF, Bonfim GF, Nogueira AS, Wanke B: Clinical and epidemiological features of 123 cases of cryptococcosis in Mato Grosso do Sul, Brazil. Rev Inst Med Trop Sao Paulo 2008, 50:75-78.

17. Trope BM, Fernandes ALC, Halpern M, Maceira JP, Barreiros MGC: Paniculite criptocócica em transplantado renal. An Bras Dermatol 2008, 83:233-236.

18. Lin X: Cryptococcus neoformans: Morphogenesis, infection, and evolution. Infect Genet Evol 2009, 9:401-416.

19. Park BJ, Wannemuehler KA, Marston BJ, Govender N, Pappas PG, Chiller TM: Refocusing on a re-emergent disease: the current global burden of cryptococcal meningitis among persons living with HIV/AIDS, The 48th Annual ICAAC/IDSA 46th Annual Meeting. Washington, DC: ASM; 2008.

20. Ministério da Saúde do Brasil - Dados e pesquisa em DST e AIDS: Coordenação do programa nacional de DTS/AIDS. Brasília: 2002. site: www.aids.gov.br.

21. Pappalardo MCSM, Melhem MSC: Cryptococcosis: a review of the Brazilian experience for the disease. Rev Inst Med Trop Sao Paulo 2003, 45:299-305.

22. Sanglard D: Importancia clínica de los mecanismos de resistencias a los antifúngicos en las levaduras. Enferm Infecc Microbiol Clin 2002 20:225-234.

23. Brouwer AE, Rajanuwong A, Chierakul W, Griffin GE, Larsen RA, White NJ, Harrison TS: Combination antifungal therapies for HIV-associated cryptococcal meningitis: a Randomized trial. Lancet 2004, 363:1764-1767.

24. Bivanco FC, Machado CDAS, Martins EL: Cutaneous cryptococcosis. Arquivos Médicos do ABC 2006, 31:102-109.

25. Gupta AK, Cooper EA: Update in Antifungal Therapy of Dermatophytosis Mycopathologia 2008, 166:353-367.

26. Cunningham A, Martin SS, Langenheim JH: Labd-13-en-8-ol-15-oic acid in trunk resin of Amazonian Hymenaea courbaril. Phytochemistry 1974, 13:294-295.

27. Marsaioli AJ, Leitão Filho HF, De Campello JP: Diterpenes in the bark of Hymenaea coubaril. Phytochemistry 1975, 14:1882-1883.

28. Busato AP, Vargas-Rechia CG, Reicher F: Xyloglucan from the leaves of Hymenaea courbaril. Phytochemistry 2001, 58:525-531.

29. Nogueira RT, Shepherd GJ, Laverde A, Marsaioli AJ, Imamura PM: Clerodane-type diterpenes from the seed pods of Hymenaea courbaril var. stilbocarpa. Phytochemistry 2001, 58:1153-1157.

30. Mujwah AA, Mohammed AM, Ahmed MH: First isolation of a flavonoid from Juniperus procera using ethyl acetate extract. Arabian J Chem 2010, 3:85-88

31. Piacente $S$, Balderrama L, De Tommasi N, Morales L, Vargas L, Pizza C: Anadanthoside: a flavanol-3-O- $\beta$-D-xylopyranoside from Anadenanthera macrocarpa. Phytochemistry 1999, 51:709-711.

32. Baderschneider $B$, Winterhalter $P$ : Isolation and Characterization of Novel Benzoates, Cinnamates, Flavonoids, and Lignans from Riesling Wine and Screening for Antioxidant Activity. J Agric Food Chem 2001, 49:2788-2798.

33. Clinical and Laboratory Standards Institute (CLSI): Reference method for broth dilution antifungal susceptibility testing of yeasts, Approved standard. CLSI M27-A3(28). 3rd edition. Wayne, PA: Clinical and Laboratory Standards Institute; 2008.

34. Clinical and Laboratory Standards Institute: Reference method for broth dilution antifungal susceptibility testing of filamentous fungi; approved standard, CLSI document M38-A2. 2nd edition. Wayne, PA: Clinical and Laboratory Standards Institute; 2008 
35. Santos DA, Barros MES, Hamdan JS: Establishing a method of inoculum preparation for susceptibility testing of Trichophyton rubrum and Trichophyton mentagrophytes. J Clin Microbiol 2006, 44:98-101.

36. Borenfreund $\mathrm{E}$, Puerner J: A simple quantitative procedure using monolayer cultures for cytotoxicity assays (HTD/ NR-90). J Tissue Cult Meth 1984, 9:7-9.

37. ICCVAM: Current status of in vitro test methods for identifying ocular corrosives and severe irritants: bovine corneal opacity and permeability test method, $\mathrm{NIH}$ Publ no. 06-4512. National Toxicology Program (NTP) Interagency Center for the Evaluation of Alternative Toxicological Methods (NICEATM). 2006. Available: http://iccvam.niehs.nih.gov/docs/ocutox_docs/ocubrd/bcop/bcopbrd. pdf.

38. Cowan MM: Plant products as antimicrobial agents. Clin Microbiol Rev 1999, 12:564-582.

39. Mallikharjuna PB, Rajanna LN, Seetharam YN, Sharanabasappa GK: Phytochemical studies of Strychnos potatorum Lf-A medicinal plant. J Chem 2007, 4:510-518.

40. Kuete V: Potential of Cameroonian plants and derived-products against microbial infections: A review. Planta Med 2010, 76:1479-1491.

41. Mandalari G, Bisignano C, D'Arrigo M, Ginestra G, Arena A, Tomaino A, Wickham MSJ: Antimicrobial potential of polyphenols extracted from almond skins. LAM 2010, 51:83-89.

42. Bisignano C, Filocamo A, Faulks RM, Mandalari G: In vitro antimicrobial activity of pistachio (Pistacia vera L.) polyphenols. FEMS Microbiol Lett 2013, 341:62-67.

43. DeVito JÁ, Mills JÁ, Liu VG, Agarwal A, Sizemore CF, Yao Z, Stoughton DM, Cappiello MG, Barbosa MD, Foster LA, Pompliano DL: An array of target-specific screening strains for antibacterial discovery. Nat Biotechnol 2002, 20:478-483.

44. Hutter B, Fischer C, Jacobi A, Schaab C, Loferer H: Panel of Bacillus subtilis reporter strains indicative of various modes of action. A A C 2004, 48:2588-2594

45. Huber J, Donald RGK, Lee SH, Jarantow LW, Salvatore MJ, Meng X, Painter R, Onishi RH, Occi J, Dorso K, Young K, Park YW, Skwish S, Szymonifka MJ, Waddell TS, Miesel L, Phillips JW, Roemer T: Chemical genetic identification of peptidoglycan inhibitors potentiating carbapenem activity against methicillin-resistant Staphylococcus aureus. Chem Biol 2009, 16:837-848.

46. Varma SR, Godavarthi A, Vidyashankar S, Nandakumar KS, Patki PS: Evaluation of in vitro toxicity of Rumalaya liniment using mouse embryonic fibroblasts and human keratinocytes. Int I Green Pharm 2011, 5:1-5.

47. Britton RG, Horner-Glister E, Pomenya OA, Smith EE, Denton R, Jenkins PR, Stewart WP, Brown K, Gesher A, Sale S: Synthesis and biological evaluation of novel flavonols as potential anti-prostate cancer agents. Eur J Med Chem 2012, 54:952-958.

doi:10.1186/1472-6882-14-245

Cite this article as: da Costa et al: Antifungal and cytotoxicity activities of the fresh xylem sap of Hymenaea courbaril L. and its major constituent fisetin. BMC Complementary and Alternative Medicine 2014 14:245

\section{Submit your next manuscript to BioMed Central and take full advantage of:}

- Convenient online submission

- Thorough peer review

- No space constraints or color figure charges

- Immediate publication on acceptance

- Inclusion in PubMed, CAS, Scopus and Google Scholar

- Research which is freely available for redistribution 